\title{
CURATING A DECOLONIAL GUIDE: THE DETOURS PROJECT
}

[Received May 4th 2019; accepted May 23rd 2019 - DOI: 10.21463/shima.13.2.04]

\author{
Hōkūlani K. Aikau \\ University of Utah, Salt Lake City, USA <h.aikau@utah.edu> \\ Vernadette Vicuña Gonzalez
}

University of Hawai'i at Manoa <vvg@hawaii.edu>

\begin{abstract}
This essay meditates on the archipelagic sensibilities and knowledge that provide the foundation for the Detours project, an edited collection that subverts the guidebook authorship and authority about the islands of Hawai'i. It braids the political history of the islands with the intellectual genealogies of postcolonial feminists writing about islands that generated the project's conceptualisation. These political energies and formations of knowledge are reflected in the substance of the art, poetry, and essays that are curated in the collection. The essay outlines the ethical dimensions of the project and the process of turning away from the guidebook genre toward a book that guides readers to decolonisation - a template and archive of place-based work and representations aimed at achieving ea (life, breath, sovereignty) for the Native Hawaiian people and the Hawaiian Islands. Finally, the essay ends with a reflection on the kinds of responsibilities that island knowledges place on people who visit or live upon them, offering a relationship of reciprocity in place of extraction.
\end{abstract}

KEYWORDS: decolonialism, sovereignty, genealogy, tourism, Indigenous resurgence

NOTE: This article does not italicise - or otherwise differentiate - indigenous language terms from standard English language ones in order to avoid the "othering" of these terms within the hegemony of English Language discourse that has served to marginalise and delegitimise indigenous cultures and languages.

\section{Introduction}

In 1993, the late Tongan scholar/poet Epeli Hau'ofa presented a scathing critique of the dominant paradigm, grounded in continental notions, of the Pacific Islands as small and, thus, insignificant places in a vast ocean. Instead he offered a cartographic and epistemological shift born out of Oceanic and Indigenous ontologies that recognise the sea as that which connects the islands and as a deep and ever-expanding source of knowledge. Hau'ofa's notion of a sea of islands has inspired more recent moves towards archipelagic

Shima <www.shimajournal.org> ISSN: 1834-6057 
and aquapelagic epistemologies, emphasising the relationships among the ocean, islands, and the peoples who call them home.

While the Detours project (Aikau and Gonzalez [eds], forthcoming 2019) was initially conceived through the framework of an alternative guidebook, at its heart, it is a project profoundly grounded in archipelagic sensibilities. The stories - written and visual - that we have curated into an edited collection draw deeply from commitments to the 'anina, the land which feeds us, recognising not only how the land and waters that make up Hawai'i provide physical nourishment, they also provide intellectual and ethical sustenance. Building on this understanding, we position Detours as a contribution in the genealogy identified by Hau'ofa - of a sea of islands as crucial sites and much-needed sources of knowledge, critique, and templates for decolonial futures.

Detours: A Decolonial Guide to Hawai' $i$ is an assemblage of narratives grounded in place that offers an alternative to how tourist fantasies and settler concerns have overwhelmingly defined modern Hawai'i (Skwiot, 2011; Trask, 2008). Guidebooks, travel narratives, and fiction constitute the bulk of this fantasy archive, reaching as far back as Captain Cook and his crew in the 18th Century and Mark Twain (whose career as a journalist was considerably enhanced by writing about the islands in 1866) who capture Hawai'i within a very specific Western imaginary of paradise. The guidebooks of today - the most popular genre of writing depicting Hawai' $i$ - hew to the conventions of this genre. They offer up Hawai' $i$ for easy consumption, tantalisingly claim to reveal its secrets and suggest the most efficient ways to make the most of a holiday. In other words, they orient a particular relationship to the islands and its people. The power of the guidebook also seeps into and affects the everyday lives of Native Hawaiians and other residents of the islands. "Paradise" requires the upkeep and support of the state and workers that prop up its service economy - they, too, must be willing participants in this collective fantasy.

Overdetermined as a tropical paradise, Hawai'i's present-day struggles with colonialism, military occupation, Native Hawaiian dispossession, lack of food sovereignty, environmental degradation, unsustainable economies and climate change are elided by these sedimented narratives of paradise. ${ }^{2}$ In tandem with the occlusion of these damaging colonial legacies from Hawai'i-as-paradise, these narratives have no place for the long and interlinked genealogies of Kanaka 'Ōiwi resistance against and refusal of colonialism, capitalism and militarism, nor for Indigenous practices of cultural and political resurgence. ${ }^{3}$ In Detours, these stories take precedence, articulating a body of work expressed through essays, poetry, art, and mapping, that are aimed at decolonising Hawai $i$ and restoring ea (sovereignty, independence, breath). In first conceptualising Detours, we took seriously the power of form and the reading practices, imaginaries and publics produced by the guidebook genre - its power to manifest the fantasies of the exotic into actual material island destinations but also recognised that we would need to ultimately depart from it in order to do justice to the counter-portraits and projects that draw on epistemologies and ontologies steeped in the 'aina (the land), the oceans) and the lives they sustain.

This essay outlines the genealogical roots and routes of Detours, its evolution from its initial conception as an alternative guidebook, the ethical dimensions that arose during the

\footnotetext{
${ }^{1}$ See Dick (2015) on the concept of the aquapelago as constituted through place and performance.

${ }^{2}$ We use the terms Native Hawaiian, Kanaka 'Ōiwi, 'Ōiwi and Kānaka interchangeably to refer to the Indigenous peoples of Hawai'i.

${ }^{3}$ See Cheer, Cole, Reeves, and Kato (2017) for expanded discussion of tourism's impact on islandscapes.
} 
process of curating and workshopping over three dozen contributions, and its ongoing story. As an initial, and incomplete, archive of the directions, shapes, and value of decolonial projects that Native and non-Native people alike have nurtured on these islands and beyond, it is our modest hope that Detours can also be a template for ongoing work both in Hawai' $i$ and elsewhere, manifesting a different vision of the world into being, one that is founded on the truth of islands as interconnected and abundant, or as Hau'ofa puts it: "vast," "expanding," "hospitable and generous" (1993: 16).

\section{Genealogies: Roots and Routes}

The critical mass of collective knowledge and experiences captured in Detours was born from many generations of political and intellectual struggle around sovereignty, decolonisation, social and economic justice, and peace in Hawai' $i$, the broader Pacific and globally. As the co-editors for the project, we also work through the lens of postcolonial, Indigenous, women of color feminist critique and activism to understand and confront the concerns of women living on islands. Often converging with each other, these genealogical routes represent a depth of island knowledge rooted in the conditions of life under capitalist, imperialist extraction and occupation. In short, the political and intellectual underpinnings of this project are woven from a global energy toward self-determination that manifested in Hawai' $i$ in very specific ways in the 196os and 1970s, laying the groundwork for the sense of connection and vision for alternative futures that have emerged and taken shape in its aftermath.

In Hawai $i$, class-based conflicts over housing, land, and water in the 1960 s and 1970 s connected to global worker and peasant movements, and also increasingly drew on 'Öiwi genealogies to understand the human relationships and obligations Kānaka have to the land, and vice versa (Goodyear-Ka'ōpua, Hussey and Wright, 2014). Linking land dispossession and political sovereignty that undergirded the struggle over development to historical and contemporary empire, the emergent Native Hawaiian sovereignty movement also connected fervent antiwar sentiment to the U. military's occupation of the Hawaiian lands, which rendered Hawai' $i$ into a laboratory for military maneuvers and weapons testing and a geostrategic launching pad for its "hot wars" in Asia (Man, 2015; Gonzalez, 2013). From the 1970s to the 1990s, anti-eviction, anti-war, and pro-sovereignty politics became increasingly vocal and visible in the islands, using an array of tactics, including legal action, street protests and occupations, to reclaim power and land.

The political movements drew from and reinvigorated Kanaka 'Ōiwi epistemologies and practices, which had persisted despite a century of occupation and assimilation, generating a critical intellectual infrastructure and cultural network that would sustain and diversify. The institutional integration of Kanaka 'Öiwi knowledge into universities and curriculum, and the revival of 'ōlelo Hawai' $i$ (Hawaiian language) are the results of these developments (Goodyear-Ka'ōpua, 2013; Warner, 1999). Some of these practices drew from reactivated links with other Pacific Island cultures, such as the revival of star navigation for oceanic voyaging (Diaz and Kauanui, 2001; Finney, 1994). Others were the result of illuminating previously forgotten or hidden mo'olelo (histories) (Silva, 2004). The Kanaka 'Ōiwi cultural and political renaissance reframed islandness away from continental militaristic and touristic logics of extraction and towards Moananui (the vast Ocean that connects our islands and our people). 
Much of the political, cultural, and intellectual work of the movement was taken on by women, despite the high visibility of men in the movement. As Noelani Goodyear-Ka'oopua (2018) notes in her account of the experience and mana (power/authority) of Native women who came of age during this period, women felt the burden and sting of occupation in particularly acute ways that had to do with how gender compounded racist structures of occupation. Militarism and tourism, the twin dominant engines of the settler state economy in Hawai' $i$, then and now, draw on sedimented gendered and sexualised tropical fantasies about island women and island life. These fantasies were not innocuous or merely symbolic: they shape material realities around types and conditions of labor, state spending and political priorities, natural resource management (or mismanagement), environmental impacts-all of which are reproduced in the realm of the home through intimate relationships.

The genealogies that form the roots of this project come from the experience of Indigenous islander women who have struggled, written, and created art about what it means to live in places that have been defined by the terms of outsiders and their systems of value. As feminist scholars of empire, we share intellectual genealogies informed by the trenchant work of Haunani-Kay Trask, who laid out a critique of the apparatuses of settler life that were diametrically opposed to Native life. Trask unflinchingly characterised Hawai'i's tourism industry as prostitution, identifying the sexualised economies of power that rendered the islands into commodities for the taking. At the height of the sovereignty movement, she famously disinvited tourists to Hawai'i, reversing the implied welcome of the friendly native, declaring:

if you are thinking of visiting my homeland, please don't. We don't want or need any more tourists, and we certainly don't like them. If you want to help our cause, pass this message on to your friends. (1993: 196).

Trask recognised the soft-core fantasy of tourism's invitation as concealing the brute logics that had rationalised the long arc of occupation and militarisation as consensual. In Hawai' $i$, tourist and settler desires overthrew a monarchy and continue to justify the present-day dispossession of Kanaka 'Ōiwi, the Indigenous peoples, and the archipelago (ibid).

Similarly, Jamaica Kincaid, in writing about Antigua in A Small Place (1988) observes that the smallness of islands is often accompanied with big desires, which become the basis of a colonial alibi. The implied invitation attributed to island peoples and geographies is underpinned by the libidinal logics of empire - what Anne McClintock has aptly described as the "porno-tropical" (1995). This invitation is continually (re)productive, translating culture into consent, reshaping hospitality into service economies, and staking claims that are solidified by occupation (Imada, 2012). Kincaid outlines tourism as the most recent incarnation of colonial desire and extraction, describing its effects on a racialised service industry reminiscent of the plantation, and on the tourist's expectations of continued access, availability, and pleasure. She addresses the tourist, "you needn't let that slightly funny feeling you have from time to time about exploitation, oppression, domination develop into full-fledged unease, discomfort; you could ruin your holiday" (Kincaid 1988: 10).

Coming from Islander women who have so often been conflated with assumptions of accommodation and access, these retractions of the invitation are jarring and unnatural (Williamson, 1989). Trask and Kincaid's rhetorical moves are refusals of that identification as well as deliberate reversals of a gaze which has for so long confined Indigenous and island

Shima Volume 13 Number 22019

-14 - 
life to colonial imaginations and desires. As editors of a project that contends with the power of Hawai'i's representation as paradise, the reversal of aloha and the invocation of 'a'ole (no, never) by Indigenous women-who so often are made the shorthand of invitation-was powerful.

While Trask and Kincaid unsettle the tourist by placing him squarely within the arc of colonialism and extraction, we also took note of other perspectives that nuance the realities that islanders grapple with. Thinking through how the militarisation of the Pacific permeates the intimate geographies of islander life, often working in tandem with the invitation to colonialism, Teresia K. Teaiwa notes that these economic structures have become a means for survival for Fijians and others. Where tourism has made itself indispensable and inextricable to these "small places," it is sometimes seen as a more palatable alternative to militarisation. She notes that many islanders don't have the luxury of rejecting what "militourism" offer and ruminates on the "processes that... have long ringfenced the Pacific Islands region... while paradoxically enabling Pacific people to travel, settle, work, serve, fight and visit as far away from our ancestral lands as we could go" (2016: 851 ). Yet she also understands these processes as things that can "just as powerfully... be recruited into native and indigenous agendas" that can be decolonising (ibid: 852). Noting that militourism can be turned on its head, Teaiwa instead finds hope in survival, in the subtle bending of form and content to different, self-determining, ends.

That these unflinching rejections or deflections of tourism, militarism, and other modes of oppression and occupation in favor of different relations to place were already taking place in Hawai'i became apparent at the American Studies Association conference in 2016. As we listened to panel after panel featuring work specific to Hawai' $i$, it became clear that there was a critical mass of the kind of place-based projects that intentionally moved Hawai'i away from the tourist fantasy. Some of these projects deliberately grappled with settler structures of power and sedimented colonial desires that have come to define the islands and its people, others turned fully to Indigenous resurgence efforts on their own terms. We realised that we could contribute to building a different vision of Hawai'i's past, present, and future by curating this emergent and powerful work as an alternative guidebook to Hawai' $i$ - one that would follow its conventions but offer radically different and unfamiliar narratives of place. In lieu of the exoticised representations of the islands in Let's Go, Fodor's and others, Detours would map Hawai'i according to the terms of Native and non-Native people working toward decolonisation. ${ }^{4}$

\section{The ever-expanding Archipelagos of Resistance and Decolonisation}

Almost as soon as the idea of an alternative guidebook to Hawai'i coalesced, our way forward took an important detour around the issues of just how much the genre would determine content, and how our content resisted the guidebook genre. We set out conceptualising the book as an intervention that would not evade the complex history of Hawai'i's overthrow, but more importantly, would delve into the different kinds of rooted work that envision, remake and return the islands as a sovereign Indigenous place. How could we and our contributors write about Hawai'i without falling into the trap of the guidebook with its premise of mobility and promise of access? Given how Hawai'i is so overdetermined by the

\footnotetext{
${ }^{4}$ There have been other ways in which the guidebook has been "perverted," most notably the series $A$ People's Guide, authored by Laura Pulido, Laura Barraclough and Wendy Cheng.
} 
tourist imaginary, how might a collection of place-based narratives instead frame an encounter that refuses this imaginary as something worth understanding and engaging in? How do we balance writing about place in loving detail and aloha without making it an open invitation? How do we make clear that there is a protocol for engaging - or even not engaging - with certain places depending on one's positionality?

As editors who are both islander women with very specific and distinct relations to Hawai $i$, we also struggled with our kuleana (responsibility, authority, privilege) with regard to this project. One of us (Hōkūlani) is Kanaka 'Ōiwi born in the islands but raised away from them. The other (Vernadette) is a Filipina settler to Hawai'i. While we had the academic training and the support of presses interested in the project, we did not necessarily have the genealogical connections to place that might authorise taking the lead on a project like this. As we reached out to possible contributors, requesting the thoughts of people we trusted on the integrity of the early proposal, the early process became a gauge for permission. We also forged a collective visioning and revisioning path that invited collaborative feedback on contributions, where clearer critiques and directions for the individual contributions and the project as a whole were crafted.

Because we were careful to reach out to people - activists, artists, academics, community leaders - who were doing different kinds of place-based work, the project's vision and goals were immediately challenged in generative and important ways. A collective critique about the guidebook's implicit invitation was crucial to the shift in the entire project. Some people were concerned about the guidebook effect of driving tourist traffic to places that are not meant for them, or having tourists take the educational tours that some of our contributors had created and not fully grappling with the issues. While we asked those of our contributors who were writing pieces - particularly those more at home in academic language - to write in more accessible prose, some also made the argument that the introduction, definition, and discussion of certain terms and concepts was also important to shifting how people approached Hawai'i. Other contributors gently but firmly checked the impulse of others to write in travelogue form. Later on, others pushed back on the issue of using 'olelo Hawai' $i$ and the politics of translating or not translating certain terms. As editors, we were grateful for the loving and generous critique from our contributors: it was evidence not only of their trust in our stewardship, but also their investment in the project. The final shape of the book owes much to them and their willingness to assert their critiques as it does to their individual offerings.

As we began to assemble the contributions in their first full form, what became apparent was that we were no longer editing something that was a guidebook. Rather what had emerged was a guide to how to live or practice decolonisation in Hawaili. This shift in the purpose of Detours not only addressed our initial questions about genre and content, but also reframed our guiding question entirely: What does it mean to curate an archipelago with an eye to decolonisation and sovereignty? We all became more interested in a genre that would not lay out Hawai i for consumption and access, but rather illuminate and archive the specifically decolonial stories that was the beating heart of the work.

In the end, we framed the project around mo'oku' auhau - as contributing to a long genealogy of resistance and refusal of colonisation, racialisation, militarism, tourism, and dispossession. As Brandy Nālani McDougall suggests, mo 'okū'auhau is a way of expressing "the 'rhetorical archipelago' of Hawai' $i$ as a continuing lāhui (nation, people)" (2017: 260). McDougall uses the concept of rhetorical archipelagoes as a way to highlight the process by which islands and continents come to be unified. In Hawaili, we might understand the links 
that connect islands embraced by oceans as a kind of mo'o - succession, series, line, lineage; a small fragment of a larger piece - ever-expanding and contracting. Mo'o, is a prefix and suffix to mo'olelo (story), mo'okū'auhau (genealogy), kuamo'o (path/trail), iwikuamo'o (backbone): the mo'o in all of these examples emphasises how a piece, a segement is a part of a whole or part of a much larger succession of words in a story/history, ancestors in a family lineage, stones in a path, vertebrae in the back, islands in a chain of islands. In this sense, Detours illuminates the lineage-the past that stretches into the present towards the futures - of lāhui Hawai'i. It is a departure, indeed, from the superficiality of a guidebook, which dismembers and dissects place according to tourist desire.

In its current form, we are pretty clear about what Detours does: it offers decolonial encounters with place through a range of storytelling grounded in place. Our goals are twofold. First, we seek to disrupt tourism's hold on the narratives about Hawai'i, and provide alternative viewpoints and approaches that allow for a deeper understanding of what lies beneath the façade of paradise. Second, the essays, personal reflections, artwork, and maps that make up Detours provide examples of how activists, academics, and communities are working to radically disrupt these frames to restore and nurture ea - what Noelani Goodyear-Ka'ōpua has described as sovereignty, life, and breath that "requires constant action" (2014: 3). The stories, maps, art, and tours that make up Detours are meant to unsettle, disquiet, and disturb the "fact" of Hawai'i as tourist paradise and military stronghold, but they are also there to establish and drive home the existence of a lāhui in the midst of becoming.

The nature of the contributions we solicited and received reshaped the book itself. Even as we had shifted into perverting the guidebook form, part of what guided our curation process was the notion of organising the entries by island, which is a common way that guidebooks approach place. While the final contributions gesture toward representation across the islands, they also signal themes that resonated with Indigenous resurgence, which then emerged as the organising rubrics for the collection. These themes make clear the waiwai (value, wealth, a word whose root, wai, means water) of Indigenous island knowledge and culture.

Wahi Pana (storied places) groups together art, poetry, and stories about specific places in the first section of the book. In contrast to touristic, capitalist, continental, and military paradigms of island space, which have often defined Hawai' $i$ as a destination, real estate, or a target, a Kanaka 'Öiwi value system of land views place through a familial relationship, as elder sibling. 'Āina, the word for land, also means "that which feeds us," and encapsulates the reciprocal relationship of responsibility and care to a relative. Wahi pana recognises this sacred charge and our first priority and responsibility. The pieces assembled in this section note the sacredness of place and how it is infused with family genealogies and understood through Indigenous geography. Opening the section, Kamanamaikalani Beamer's account of Hawaiian land division systems describes the intimacy of Indigenous relations to the 'aina. Relatedly, closing the wahi pana collection is a loving, detailed mele (chant) or cartographic story of the coast of Keaukaha on Hawai' $i$ that asserts the authors' stewardship and connection to the places they call home. ${ }^{5}$

Other pieces in the Wahi Pana section document the tensions and changes brought by tourism, development, or militarisation, and the ways that communities have fought back

\footnotetext{
${ }^{5}$ See Nogues (2017) for examples of poetry and art as modes for resisting militarism.
} 
or adapted. In Uncle Joe Estores and Ty P. Kāwika Tengan's reminiscences about the lands and waters around Fort Kamehameha and 'Āhua Point on O'ahu, the memories of land and waters that could sustain and feed families are overwritten by pollution from military development. Others describe outright desecration, such as artist Kapulani Landgraf s visual photographic series of the destruction of sacred pu'u (hills) to mine the materials to produce sand for beaches elsewhere. Whether written as love letters or elegies, the contributions in Wahi Pana illuminate the interconnection between Indigenous geography and archipelagic epistemologies that connect people to the 'aina as the foundation for a decolonial consciousness.

The works gathered in the next section, Hana Lima (working with the hands) recognise that decolonisation requires labor - day after day, generation after generation - and reflects the diversity of efforts for restoration and transformation. From creative work that shifts perceptions and provokes critical thinking; to meditations on re-establishing, adapting, and teaching cultural protocols and practice under new conditions; to the vexed negotiations of communities against developers and tourists; and the struggles defined by Indigenous refusals to protect sacred places, this labor is fueled by aloha 'āina, love for the land. Hana lima is the multi-pronged, on-going, inventive work of restoration and resurgence. The section begins with a poetic analysis of aloha as deoccupied practice, transitions to a trenchant reminder that a 'ole is refusal to US overtures of recognition and assimilation, and arrives at a future being built one stone at a time through restoration projects such as Keawanui fishpond on Moloka'i or traditionally built hale (houses) in Maui. Here, contributors demonstrate how ancestral knowledge is enlivened through the revival of traditional Hawaiian hale and heiau (altar) building methods and the passing down of traditional salt-making practices. They upend expectations with art that hijacks the postcard through humorous (re)narrations of overthrow instead of depictions of hula girls. They bear witness to the constant struggle against colonial encroachment - most recently through the ongoing battle against the construction of Thirty Meter Telescope on the sacred mountain, Mauna Kea.

Actual tours and itineraries make up the third section: Huaka'i. Distinct from the kinds of excursions outlined in guidebooks, the term huaka'i describes journeys whose purpose is knowledge and transformation. Some huaka'i highlight histories buried under concrete, or the palimpsest of histories in tension in one place. Many of the huaka'i offered in this section are grounded in genealogical ties to place, as well as the research and work to establish disruptions to these genealogies. Aunty Terri Keko'olani and Kyle Kajihiro's demilitarisation DeTour (to which we owe the title of the book) introduces its participants to the history of overthrow, the landscape of US militarisation, layers of Indigenous history and, finally, a present-day decolonial project adjacent to Pearl Harbor/Pu'uloa. A similar kind of arc is described in a huaka'i of the island of Kaho'olawe, which was used by the US Navy as a practice bombing target for decades. Still others describe huaka'i as a community tactic for narrating place in response to different kinds of colonial encroachments.

The final section of Detours expands the guidebook's traditional understanding of destination as bound by borders. Working archipelagically from the place of islands allows us to rely upon islander notions of the relationships that are always already in place among, land, sea, sky, and people. As Alice Te Punga Somerville reminds us, "[w] hen the island is a starting point, it does not need to first be an anticontinent, and so the step from the bounded island to the entangled archipelago is unnecessary' islands are already experienced and understood as having multiple connections to other land and liquid spaces" (2017:322). Here, we expand the pae "äina (archipelago) beyond the "big eight" islands typically covered 
by guidebooks to encompass the places where Hawaiians have ventured, voyaged, and settled as a matter of coercion or opportunity (Cook, 2018; Chang, 2016). This section also tracks the kind of kuleana of people who have settled in Hawai'i from elsewhere, and of Hawaiians who have settled elsewhere, often on the lands of other Indigenous peoples. At the heart of this section is the notion of kuleana, no matter how far from home we all wander we carry the responsibility to support the decolonisation efforts of the Native peoples' upon whose land we derive sustenance.

\section{A'ole I Pau}

The lāhui Hawai'i (the Hawaiian nation) has tactically, strategically, and persistently resisted dismemberment and military occupation (Osorio, 2002; Kajihiro, 2008). In its curation of stories about place and relationships of accountability to place, Detours actively contributes to and illuminates part of a broad and multifaceted effort toward decolonising Hawai'i. While Detours offers examples of how people, variously positioned in relationship to Hawai' i, are working to restore $e a$, we also want to leave readers with the idea that the work of decolonisation is something that can happen anywhere. We end this essay where we end our introduction, with the statement "A'ole i pau" - the work is not yet finished. Indeed, if we take seriously Eve Tuck and Wayne Yang's call that decolonisation is not a metaphor, then our hope for the book is that it exhorts its reader to continue the work of decolonisation in the places that they live. (Tuck and Yang, 2012).

We hope that Detours prompts people to also ask questions about the places they live, and not only the ones they visit. Following Trask and Kincaid's direct address to the tourist, we ask: who are the Indigenous peoples in the place where you live and what is their name for that place? What are the on-going political, social, and economic struggles of the Native peoples upon whose land you live? How can you support the work of decolonisation in the place you call home? When we consider the work we are doing with Detours, we are doing more than implicitly asking the reader to consider the work that still needs to be done. We are explicitly asking that they learn about and take up the call to decolonise their relationship to the lands where they live, dwell and work by cultivating ea, or whatever the equivalent term is in the Indigenous vernacular of the place where they live. A'ole I ka pau, the work, then is not done and the archipelago of resistance, decolonisation, and Indigenous resurgence continues to grow and expand.

\section{BIBLIOGRAPHY:}

Aikau, H.K and Gonzalez, V.V (eds) (forthcoming 2019) Detours: A Decolonial Guide to Hawai $i$, Durham: Duke University Press

Chang, D (2016) The World and All the Things Upon It, Minneapolis: University of Minnesota Press

Cheer, J.M, Cole S, Reeves K.J and Kato K (2017) 'Tourism and Islandscapes: Cultural Realignment, Social-Ecological Resilience, and Change,' Shima v11, n2: 40-54

Cook, K (2018) Return to Kahiki: Native Hawaiians in Oceania, Cambridge: Cambridge University Press 
Diaz, V.M and Kaunui, J.K (2001) 'Native Pacific Studies on the Edge', The Contemporary Pacific v13 n2: 315-342

Dick, T (2015) 'Choreographing the Vanuatu Aquapelago: Engaging with Performatively Constituted Specificities of Place,' Shima v9 n2: 1-22

Finney, B (1994) Voyages of Rediscovery: A Cultural Odyssey through Polynesia, Berkeley: University of California Press

Gonzalez, V.V (2013) Securing Paradise: Tourism and Militarism in Hawai'i and the Philippines, Durham: Duke University Press

Goodyear-Ka'ōpua, N (2013) The Seeds We Planted: Portraits of a Native Hawaiian Charter School, Minneapolis: University of Minnesota Press

---- (2014) 'Introduction,' in Goodyear-Ka'ōpua, N, Hussey I, and Wright, E.K (eds) A Nation Rising: Hawaiian Movements for Life, Land, and Sovereignty, Durham: Duke University Press, 1-33

---- (2018) Nā Wahine Koa: Hawaiian Women for Sovereignty and Demilitarization, Honolulu: University of Hawai'i Press

Goodyear-Ka‘ōpua, N, Hussey I, and Wright, E.K (eds) (2014) A Nation Rising: Hawaiian Movements for Life, Land, and Sovereignty, Durham: Duke University Press

Hau'ofa, E (1993) 'Our Sea of Islands' in Waddell, E, Naidu, V and Hau'ofa, E (eds) A New Oceania: Rediscovering Our Sea of Islands, Suva, Fiji: School of Social and Economic Development. The University of the South Pacific in association with Beake House: 2-16

Imada, A.L (2012) Aloha America: Hula Circuits Through the U.S. Empire, Durham: Duke University Press

Kajihiro, K (2008) 'The Militarizing of Hawai'i: Occupation, Accommodation, and Resistance," in Fujikane C and Okamura, J.Y (eds) Asian Settler Colonialism: From Local Governance to the Habits of Everyday Life in Hawai ' $i$, Honolulu: University of Hawai'i Press 171-94

Kincaid, J (1988) A Small Place, New York: Farrar, Strauss and Giroux

Man, S (2015) 'Aloha, Vietnam: Race and Empire in Hawai'i's Vietnam War,' American Quarterly v67 n4: 1085-1108

McClintock, A (1995) Imperial Leather: Race, Gender, and Sexuality in the Colonial Contest, New York: Routledge

McDougall, B.M (2017) “We Are Not American”: Competing Rhetorical Archipelagoes in Hawai 'i,' in Roberts, B.R and Stephens, M (eds) Archipelagic American Studies, Durham: Duke University Press: 259-278 
Nogues, C (2017) '"With [Our] Entire Breath": The US Military Buildup on Guahan (Guam) and Craig Santos Perez's Literature of Resistance,' Shima v12 n1: 21-34

Osorio, J.K (2002) Dismembering Lahui: A History of the Hawaiian Nation to 1887, Honolulu: University of Hawai'i Press

Silva, N.K (2004) Aloha Betrayed: Native Hawaiian Resistance to American Colonialism, Duke University Press Books

Skwiot, C (2011) The Purposes of Paradise: U.S. Tourism and Empire in Cuba and Hawai'i, Philadelphia: University of Pennsylvania Press

Somerville, A.T.P (2017), 'The Great Pacific Garbage Patch as Metaphor: The (American) Pacific You Can't See,' in Roberts, B.R and Stephens, M (eds) Archipelagic American Studies, Durham: Duke University Press: 320 - 338

Teaiwa, T (2016) 'Reflections on Militourism, US Imperialism, and American Studies,' American Quarterly v68, n3: 851-52

Trask, H (1993) From a Native Daughter: Colonialism and Sovereignty in Hawai'i. Honolulu: University of Hawai'i Press

Trask, H (2008) 'Settlers of Color and 'Immigrant' Hegemony: "Locals" in Hawai 'i,' in Fujikane C and Okamura, J.Y (eds) Asian Settler Colonialism: From Local Governance to the Habits of Everyday Life in Hawai ' $i$, Honolulu: University of Hawai'i Press: 45-65

Tuck, E and Wayne Yang, K (2012) "Decolonization Is Not a Metaphor," Decolonization: Indigeneity, Education \& Society vı nı:

http://decolonization.org/index.php/des/article/view/18630 - accessed 15th May 2019

Warner, S.L.N (1999) “Kuleana”: The Right, Responsibility, and Authority of Indigenous Peoples to Speak and Make Decisions for Themselves in Language and Cultural Revitalization,' Anthropological \& Education Quarterly v30 n1: 68-93

Williamson, J (1989) 'Woman Is an Island: Femininity and Colonization,' in Modleski, T (ed) Studies in Entertainment, Bloomington: Indiana University Press: 111-118 